\title{
De la sindromul de colestază la transplantul hepatic
}

\author{
Irina Dijmărescu' ${ }^{1,2}$, Ruxandra Darie' ${ }^{1}$, Ana-Maria Brădeanu', \\ Mirela Luminița Pavelescu ${ }^{1,2}$ \\ ${ }^{1}$ Spitalul Clinic de Urgență pentru Copii „Grigore Alexandrescu“, București, România \\ 2Universitatea de Medicină și Farmacie „Carol Davila“, București, România
}

\begin{abstract}
REZUMAT
Introducere. Sindromul Alagille este o anomalie genetică cu transmitere autozomal dominantă și afectare pluriorganică. Diagnosticul este suspicionat la sugarii care se prezintă cu icter tegumentar în primele 6 luni de viață $(70 \%)$ asociat sau nu cu suflu cardiac (17\%).

Prezentarea cazului. Raportăm cazul unui copil de 2 ani și 2 luni de sex masculin, aflat în evidența clinicii noastre de la vârsta de 3 zile, când a fost internat pentru icter tegumentar intens și ileus meconial. Examenul clinic a evidențiat meteorism abdominal și suflu sistolic. Investigațiile de laborator au arătat nivel crescut al bilirubinei totale și directe, dar valori normale ale transaminazelor, proteinelor serice și coagulogramei. Au fost excluse cauzele infecțioase - HIV, VHB, VHC, EBV, CMV, sifilis. Ecografia cardiacă a depistat stenoză pulmonară periferică largă, fără implicații hemodinamice. Radiografia toracică nu a evidențiat modificări. A fost exclusă ca etiologie a colestazei fibroza chistică. Principala suspiciune diagnostică la acel moment a fost sindromul Alagille, însă examenul histopatologic nu a fost concludent. Au fost continuate investigațiile, iar examenul oftalmologic a evidențiat embriotoxon posterior, una dintre trăsăturile fenotipice clasice ale sindromului Alagille. Examinarea CT abdominală a decelat o imagine nodulară în segmentul IV hepatic și absența coledocului, iar colangio-IRM-ul efectuat în completare a depistat căi biliare intra/extrahepatice extrem de fine și colecist absent. Testarea genetică nu a fost disponibilă inițial, însă ulterior a confirmat diagnosticul de sindrom Alagille. Pacientul a asociat eșecul creșterii și elemente de colestază cronică: icter sclero-tegumentar intens, prurit refractar, scaune acolice, hepatosplenomegalie, xantelasme, citoliză hepatică, dislipidemie severă. Luând în considerare starea de nutriție a copilului și elementele de decompensare, s-a recomandat evaluarea în vederea transplantului hepatic și a fost îndrumat către centrul de transplant din Palermo.

Concluzii. Sindromul Alagille nu este întotdeauna un diagnostic la îndemână. În anumite situații, stabilirea acestuia și alegerea metodei terapeutice optime necesită timp.
\end{abstract}

Cuvinte cheie: sindrom Alagille, colestază cronică, eșecul creșterii
Abrevieri
CMV - citomegalovirus
CFIP - colestază familială intrahepatică progresivă
$\mathrm{CT}$ - tomografie computerizată
HIV - virusul imunodeficienței umane
GGT - gamaglutamiltransferaza
IRM - imagistică prin rezonanță magnetică
EBV - virus Epstein-Barr
SALG - sindrom Alagille
VHB - virus hepatitic B
$\mathrm{FA}$ - fosfatază alcalină
VHC - virus hepatitic C

\section{INTRODUCERE}

Sindromul Alagille (SALG), cunoscut și sub numele de displazie arterio-hepatică, este o anomalie genetică multisistemică ce implică ficatul, inima, creierul, ochii și oasele. Primele cazuri au fost raportate de Alagille în 1969. Este o patologie rară cu transmitere autozomal dominantă cauzată de defecte ce survin în calea de semnalizare NOTCH. Există 2 subtipuri ale acestei boli - mutațiile sau delețiile ce apar la nivelul genei JAG1 sunt cele mai frecvente și determină SALG de tip 1, în timp ce tipul 2 este mai rar întâlnit şi apare din cauza defectelor genei NOTCH2. Însă aproximativ jumătate dintre cazurile de sindrom Alagille sunt determinate de o mutație de novo (1-3). 


\section{PREZENTAREA CAZULUI}

Prezentăm cazul unui băiat de 2 ani și 2 luni care, la vârsta de 3 zile, în februarie 2017, s-a prezentat în clinica noastră pentru vărsături bilioase, absența eliminării meconiului și icter tegumentar intens.

Din antecedentele personale, s-a evidențiat faptul că pacientul a fost născut prematur, extras prin operație cezariană la vârsta gestațională de 35 săptămâni, scor APGAR 6, a necesitat manevre de resuscitare. Din antecedentele heredocolaterale, reținem că mama este cunoscută cu coarctație de aortă operată și prezintă trăsături faciale particulare, însă nu se află în evidență cu altă patologie. Tatăl este diagnosticat cu obezitate de grad II și steatoză hepatică.

La prima internare în clinică (la vârsta de 3 zile), nou-născutul avea o greutate de $2.320 \mathrm{~g}$, talie $46 \mathrm{~cm}$ (percentila 16, -1 deviații standard), distensie abdominală importantă, fără semne de iritație peritoneală, absența eliminării meconiului, suflu sistolic, hipotonie şi hiporeactivitate. Investigațiile de laborator efectuate la acel moment au arătat sindrom de colestază (bilirubină totală $11,6 \mathrm{mg} / \mathrm{dl}$, bilirubină indirectă $9,4 \mathrm{mg} / \mathrm{dl}$, bilirubină directă $3,3 \mathrm{mg} / \mathrm{dl}-28 \%$ din totalul bilirubinei, gamaglutamiltransferază (GGT) 425 U/1). Transaminazele, proteinele serice și coagulograma au fost în limite normale, fără sindrom biologic inflamator. Radiografia toracică și abdominală nu a evidențiat anomalii vertebrale, însă a descris importantă distensie aerică jejuno-ileală (Figura 1). Irigografia ulterioară nu a condus la eliminarea meconiului, motiv pentru care s-a practicat laparotomie pentru dezobstrucție. Postchirurgical, nou-născutul a avut o curbă ponderală lent ascendentă, icterul tegumentar s-a menținut, însoțit de urină hipercromă și scaune acolice. Valorile bilirubinei totale și ale fracțiunii directe s-au menținut crescute.

Ecografia abdominală efectuată nu a identificat aspecte patologice, iar ecografia cardiacă a descris stenoză pulmonară periferică largă, fără implicații hemodinamice. La vârsta de 9 luni, ecografia abdo-

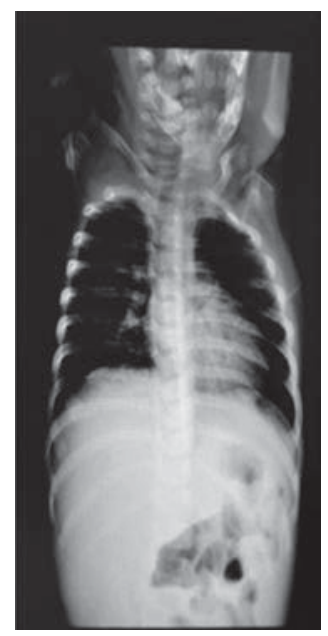

FIGURA 1. Radiografie toracică şi abdominală - importantă distensie aerică jejuno-ileală minală, urmată de CT abdominal, a identificat un ficat cu ecostructură neomogenă, cu o imagine nodulară $(26 / 18 \mathrm{~mm})$ la nivelul segmentului hepatic IV, sugestivă pentru hiperplazie nodulară benignă (Figura 2), și dilatații segmentare ale ductelor biliare intrahepatice. Carcinomul hepato-celular a fost infirmat întrucât valorile alfafetoproteinei au fost normale. Colangio-IRM-ul efectuat în completare la vârsta de 11 luni a descris un ficat mărit de volum cu prezența unei arii nodulare bine delimitate $(27 / 23$ $\mathrm{mm})$, ducte biliare intra/extrahepatice extrem de fine, absența vezicii biliare și noduli cirotici, ascită în cantitate mică. Examenul oftalmologic a depistat un element fenotipic caracteristic sindromului Alagille, embriotoxon posterior (Figura 3).

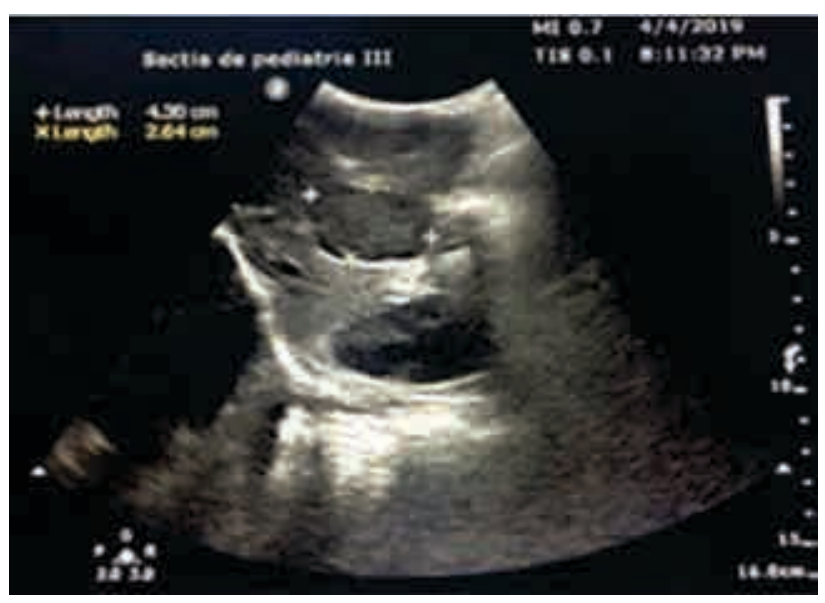

FIGURA 2. Imagine nodulară în segmentul IV

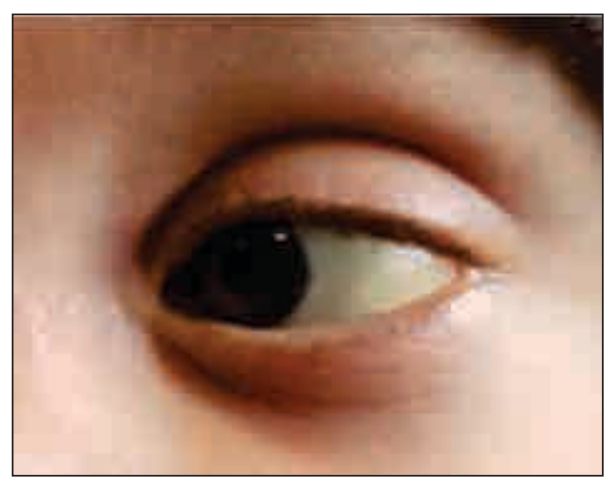

FIGURA 3. Embriotoxon posterior

Biopsia hepatică nu a fost concludentă, evidențiind fibroză portală și stază biliară cu trombi biliari la nivelul canaliculelor biliare.

În faţa unui pacient cu colestază cronică şi malformație cardiacă structurală, au fost luate în discuţie multiple diagnostice diferențiale. Etiologiile infecțioase au fost excluse - serologii pentru virusul imunodeficienței umane (HIV), virusul hepatitic B (VHB), virusul hepatitic C (VHC), virusul EpsteinBarr (EBV), citomegalovirusul (CMV), sifilis negative. Diagnosticul de fibroză chistică a fost infirmat de 
valorile normale ale testului sudorii ( $\mathrm{NaCl} 8 \mathrm{mmol} / \mathrm{l})$; testarea genetică a fost, de asemenea, negativă. Colestaza familială intrahepatică progresivă (CFIP) tip 3 , afecțiune genetică autozomal recesivă, rămâne în discuție, dar testarea genetică este indisponibilă.

În acel moment, principalul diagnostic diferenţial al sindromului Alagille era atrezia de căi biliare. Având în vedere prezența trăsăturilor faciale caracteristice ale copilului, respectiv ale mamei (facies triunghiular, bărbie ascuțită, ochi înfundați în orbite cu aparentă exoftalmie secundară și hipotelorism) (Figura 4), precum și asocierea cu stenoză pulmonară periferică largă și embriotoxon posterior (considerat ca fiind un marker fenotipic specific al sindromului Alagille), am considerat că paucitatea de ducte biliare intrahepatice este diagnosticul cel mai probabil. Testarea genetică nu a fost posibilă la momentul respectiv, însă pacientul a fost îndrumat ulterior către o clinică de transplant din Palermo, unde s-a identificat o mutație heterozigotă a genei JAG1 (varianta c.2372+3_2372+6delAAGT), confirmându-se astfel diagnosticul de sindrom Alagille.

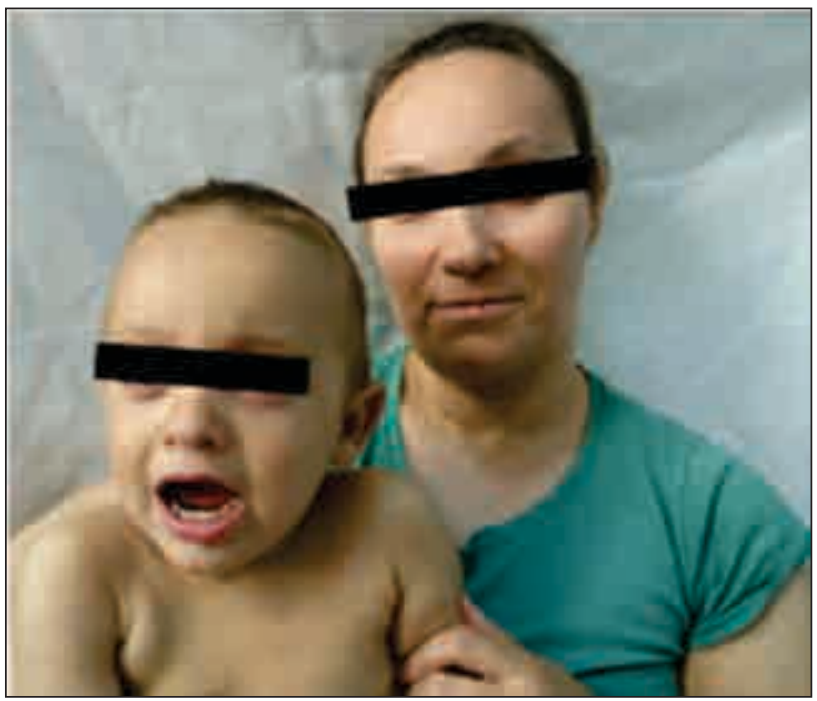

FIGURA 4. Facies particular al mamei şi copilului

În evoluție, pacientul a prezentat sindrom de colestază cronică cu elemente clinice - icter tegumentar, prurit refractar, scaune acolice, urină hipercromă, hepatosplenomegalie (Figura 5), circulație colaterală abdominală, xantelasme (Figura 6) - și paraclinice: valori constant crescute ale bilirubinei totale și ale fracțiunii directe, creșterea fosfatazei alcaline (FA), GGT-ului, hipercolesterolemie, hiperlipemie. Consecințele colestazei cronice cu malabsorbție și malnutriţie au fost, de asemenea, prezente: hipotrofie ponderală și staturală cu spor ponderal de $10 \mathrm{~kg}$ în peste 24 de luni. Progresiv, s-a instalat citoliza hepatică şi au apărut modificări ale coagulogramei.

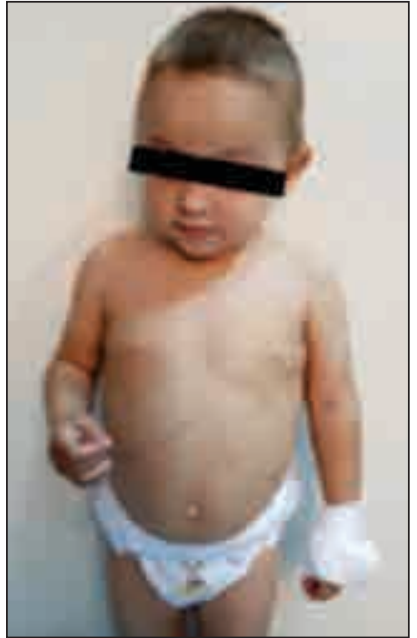

FIGURA 5.

Hepatosplenomegalie importantă

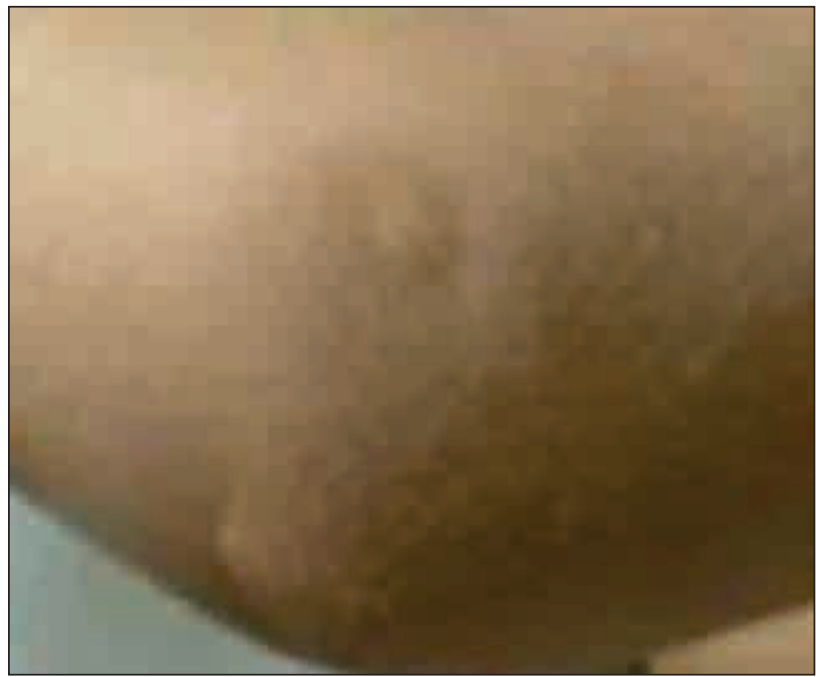

FIGURA 6. Xantelasme

Prezența decompensării parenchimatoase și vasculare, a nodulilor de neoformație și consecințelor nutriționale la un copil cu ciroză hepatică ridică problema necesităţii transplantului hepatic, deși scorul PELD (pediatric end-stage liver disease) arată un rezultat promițător $(86,8 \%$ rată de supraviețuire în așteptarea transplantului la 1 an) (Figura 7).

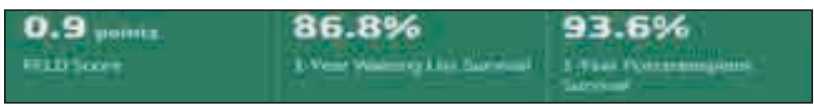

FIGURA 7. Scorul PELD (pediatric end-stage liver disease score)

Această procedură nu poate fi realizată în România în acest moment, motiv pentru care pacientul a fost îndrumat către o clinică de transplant din Palermo. La evaluarea în Centrul de Transplant din Palermo, a fost confirmat genetic diagnosticul de sindrom Alagille, s-a efectuat esogastroduodenoscopie la vârsta de 1 an şi 7 luni, care a evidenţiat varice esofagiene de grad F2, cu risc redus de sângerare. Ecografia abdominală a evidențiat structură hepatică neomogenă și nodul de neoformație de 4,37 cm (Figura 8). 


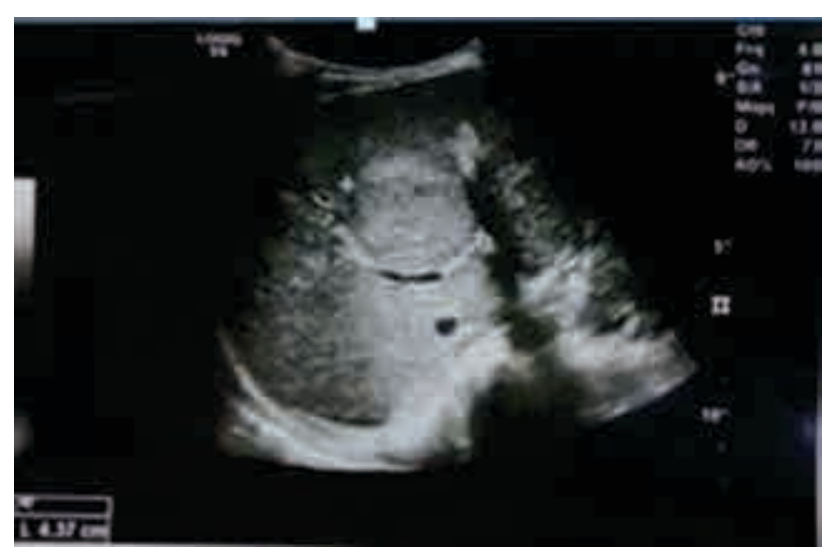

FIGURA 8. Hiperplazie nodulară benignă

Evaluările ulterioare în clinica din Palermo au evidențiat status clinic bun, curbă ponderală ascendentă cu creștere ponderală de $2 \mathrm{~kg}$ în 5 luni și funcție hepatică conservată.

Evoluția bilirubinei totale și a fracției directe a acesteia, a GGT și a FA sunt prezentate în Figura 9. Evoluția colesterolului total, trigliceridelor și lipidelor totale este prezentată în Figura 10.

\section{DISCUȚII}

Sindromul Alagille se caracterizează prin disfuncție hepatică determinată de malformația, îngustarea sau absența ductelor biliare intrahepatice cu dezvoltarea unui sindrom de colestază cronică cu icter persistent, malabsorbție, malnutriție, prurit refractar și xantoame. Boala hepatică este progresivă, conducând, în final, la ciroză și insuficiență hepatică, de aceea transplantul este necesar în aproximativ $15 \%$ dintre cazuri $(1,3)$. Pacientul prezentat a dezvoltat precoce ciroză hepatică și hipertensiune portală cu varice esofagiene grad F2, ascită la vârstă mică. De aceea, pacientul are indicaţie în acest moment de transplant hepatic în scop terapeutic.

Evaluarea severității bolii hepatice cronice este primul pas în managementul unui copil cu SALG. Colestaza persistentă presupune nivel seric crescut al bilirubinei totale cu fracțiunea directă peste $20 \%$, acizi biliari serici semnificativ crescuți, valori mari ale GGT-ului și ale FA. Nivelul crescut al GGT-ului este util și în diferențierea sindromului Alagille de

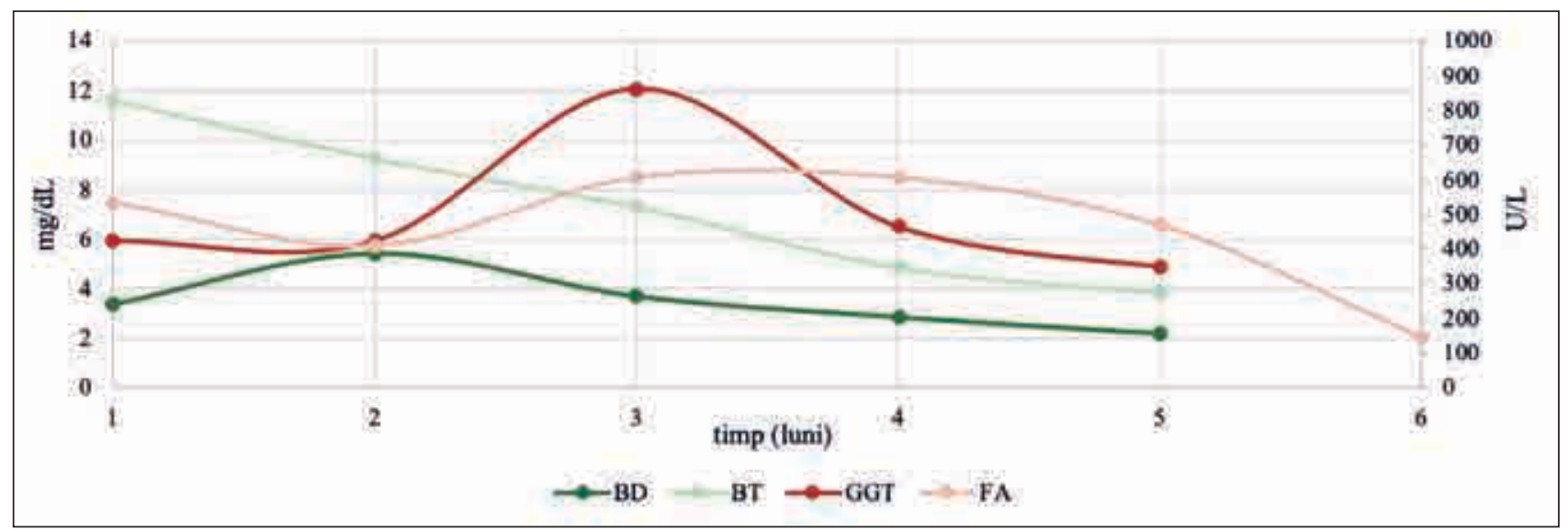

FIGURA 9. Evoluția colestazei hepatice

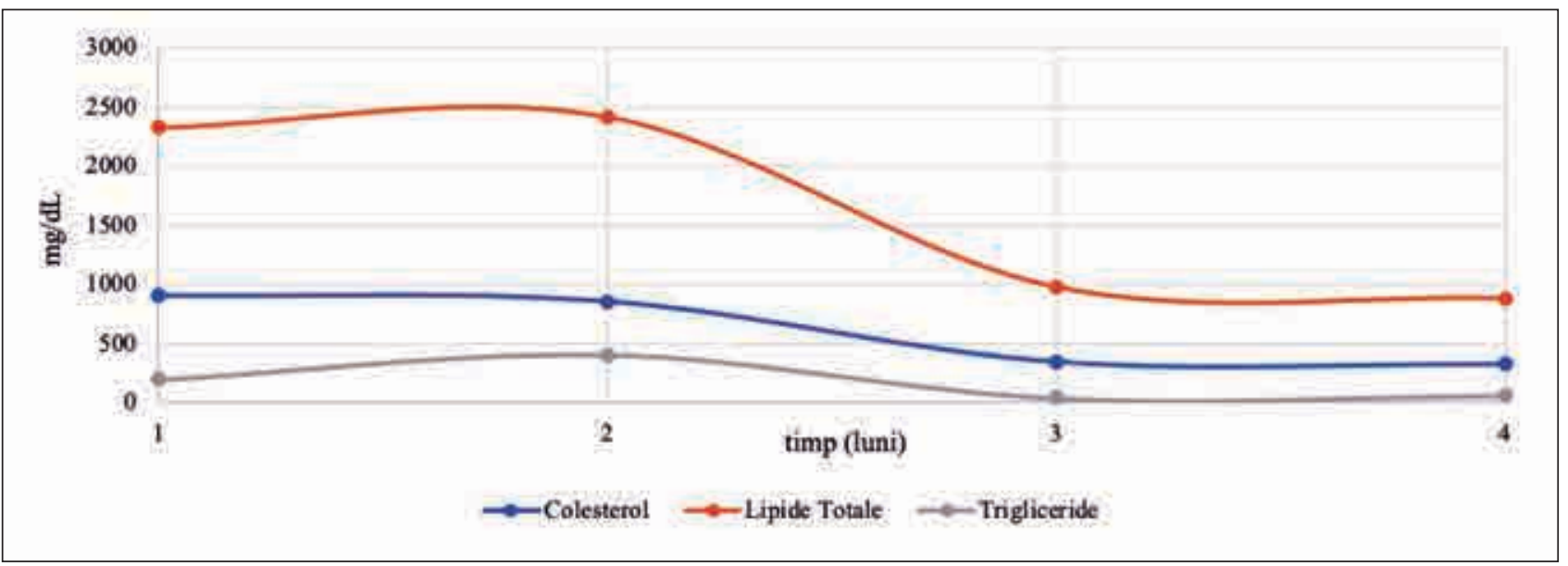


tipurile 1 și 2 ale CFIP, care evoluează cu nivel normal al acestei enzime (4). Pacientul a prezentat colestază hepatică persistentă, cu valori crescute ale bilirubinei totale (4-10 mg/dl), bilirubinei conjugate (4,5-9 $\mathrm{mg} / \mathrm{dl}$ ), ale FA și GGT-ului (400-600 U/l).

Colestaza cronică este responsabilă de malabsorbția lipidelor și vitaminelor liposolubile, astfel că un bilanț adecvat al metabolismului lipidic, al 25-hidroxivitaminei D3 și al vitaminelor A, K, E este esențial (4). Pacienții cu sindrom Alagille au nivel seric crescut al colesterolului total, al fracțiunii LDL a acestuia și al trigliceridelor ca rezultat al colestazei cronice. Din cauza unei deficiențe enzimatice (lecitin-colesterol-aciltransferaza), hipercolesterolemia din SALG se bazează predominant pe colesterolul neesterificat. Raportul colesterol liber/ colesterol esterificat poate reprezenta o analiză diagnostică utilă (2). La pacientul prezentat, se decelează o dislipidemie mixtă severă, cu valori mari ale colesterolului total și trigliceridelor (colesterol total» 300-900 mg/dl, trigliceride » 170-400 mg/dl).

Parametrii de coagulare, precum timpul de protrombină sau timpul de tromboplastină parțială activată, sunt de regulă prelungiți. Pacientul a prezentat valori normale sau ușor modificate ale coagulogramei în dinamică.

Indivizii cu sindrom Alagille pot dezvolta în timp hepatocarcinom, de aceea screening-ul ecografic și dozarea alfafetoproteinei sunt esentiale atunci când survin modificări ale arhitecturii hepatice (5). În cazul pacientului nostru, ciroza hepatică cu noduli de neoformație a fost descrisă imagistic la vârsta de 9 luni; nivelul de alfafetoproteină este normal, în această situație stabilindu-se diagnosticul de hiperplazie nodulară benignă.

Copiii cu SALG asociază hipotrofie ponderală importantă din cauza incapacității de a digera și absorbi lipidele și vitaminele liposolubile. În plus, deficitul de oligoelemente - în special calciu și zinc este frecvent întâlnit. De aceea, pacienții se confruntă cu tulburări în dezvoltare și pubertate întârziată (3). În cazul nostru, copilul a prezentat un status nutrițional deficitar și hipotrofie staturală, având greutate de $10 \mathrm{~kg}$ (percentila 2, -2 deviații standard) și talie de $82 \mathrm{~cm}$ (percentila $0,6,-2,5$ deviații standard) la 2 ani şi 2 luni.

Sindromul Alagille poate determina afectare pancreatică și, ca urmare, malabsorbția lipidică se poate accentua, contribuind la hipotrofia ponderală a acestor pacienți (3). Nu au existat semne clinice sau parametri de laborator care să indice afectare pancreatică în cazul pacientului prezentat.

Toți copiii cu sindrom Alagille ar trebui să beneficieze de un bilanț cardiologic adecvat care să identifice eventualele anomalii structurale sau electrice.
Cea mai frecventă malformație cardiacă asociată este stenoza pulmonară periferică, însă pacienții pot prezenta și alte defecte precum defectul septal atrial sau ventricular, persistența de canal arterial sau tetralogia Fallot. În plus, studii recente au raportat un subgrup de copii cu SALG care asociază sindrom de preexcitație Wolf-Parkinson-White $(1,4)$. Ecografia cardiacă a descris în cazul pacientului nostru cea mai comună anomalie structurală cardiacă din cadrul SALG - stenoză pulmonară periferică largă fără consecințe hemodinamice.

Particularitătile faciale reprezintă o caracteristică importantă a sindromului Alagille, deși în primii ani de viață acestea pot fi trecute cu vederea. Acești pacienți au frunte lată, un nas alungit cu vârf bulbos, ochi înfundați în orbite și o bărbie mică, ascuțită $(1,3)$. Am observat toate aceste trăsături faciale particulare la pacientul nostru. Același fenotip a fost identificat și în cazul mamei pacientului.

În ceea ce privește afectarea neurologică a copiilor cu sindrom Alagille, aceștia pot asocia ușoară întârziere în dezvoltare sau retard mintal (3). În cazul pacientului de față, evaluarea neurologică a descris o dezvoltare neuro-psiho-motorie corespunzătoare vârstei.

Emerick şi colab. au raportat că embriotoxonul posterior, o „linie circulară“ decolorată pe suprafața ochiului sau la periferia irisului, reprezintă cea mai comună anomalie oculară întâlnită la pacienții cu sindrom Alagille (peste 75\% dintre cazuri). Totuși, acesta a fost descris la $15 \%$ din populația sănătoasă $(1,3,4)$. În cazul de față, embriotoxonul posterior a reprezentat o descoperire importantă care a susținut diagnosticul de sindrom Alagille. Alte defecte oculare identificate includ anomalia Axenfeld, retinita pigmentară sau malformațiile de disc optic (4). Un studiu recent condus de Nischal şi colab. a raportat importanța ecografiei oculare, care descrie un nou semn asociat geodele de disc optic (6).

Copiii cu sindrom Alagille pot asocia risc crescut de fracturi osoase sau anomalii scheletale izolate, precum scurtarea radiusului, ulnei sau a falangelor, din cauza deficitului de vitamina $\mathrm{D}$ și calciu. Vertebra „în fluture“ a fost identificată la peste $50 \%$ dintre acești pacienți, însă aproape niciodată nu determină afectare funcțională a coloanei vertebrale $(3,4)$. Radiografia toracică nu a identificat anomalii vertebrale sau alte anomalii scheletale în cazul pacientului prezentat.

Leziunile vasculare, stenoze sau anevrisme ale vaselor capului şi gâtului reprezintă o anomalie amenințătoare de viață asociată sindromului Alagille (3). Kamath şi colab. au raportat că $6 \%$ dintre cazurile confirmate de atrezie biliară intrahepatică asociază malformații vasculare precum anevrismul de arteră 
cerebrală medie sau arteră bazilară, boala Moyamoya sau anomalii de arteră carotidă internă (7). Astfel de malformații nu au fost descrise în cazul pacientului nostru.

Genele JAG1 și NOTCH2 sunt implicate în structurile nefronale proximale și podocitare. De aceea, mutația lor (în cadrul SALG) determină displazie renală și o formă de proteinurie tipică sindromului Alagille. În plus, din cauza expresiei genei JAG1 la nivelul tubilor colectori, copiii cu SALG pot dezvolta acidoză tubulară renală (4). Ecografia abdominală și parametrii urinari normali în dinamică au exclus afectarea renală a pacientului nostru.

Anterior testării genetice, diagnosticul de sindrom Alagille poate fi susținut pe baza prezenței a cel puțin 3 dintre cele 5 criterii clinice majore (Tabel 1) asociate cu aspectul histologic sugestiv - paucitatea ductelor biliare intrahepatice (8).

TABEL 1. Criterii diagnostice sindrom Alagille (8)

\begin{tabular}{|l|l|}
\hline Criterii de diagnostic pozitiv & Pacient prezentat \\
\hline $\begin{array}{l}\text { Examen histopatologic sugestiv } \\
\mathbf{3} \text { din } \mathbf{5} \text { criterii majore }\end{array}$ & $\begin{array}{l}\text { Examen histopatologic } \\
\text { neconcludent } \\
+ \\
\mathbf{4} \text { din } \mathbf{5} \text { criterii majore }\end{array}$ \\
\hline CRITERII MAJORE & $\begin{array}{l}\text { 1. Colestază } \\
\text { intrahepatică }\end{array}$ \\
$\begin{array}{l}\text { 1. Colestază } \\
\text { 2. Boală cardiacă cu stenoza } \\
\text { pulmonară periferică }\end{array}$ & $\begin{array}{l}\text { 2. Stenoză pulmonară } \\
\text { periferică largă }\end{array}$ \\
$\begin{array}{l}\text { 3. Anomalii scheletale (vertebra ,în } \\
\text { fluture“) }\end{array}$ & $\begin{array}{l}\text { 3. Embriotoxon } \\
\text { posterior }\end{array}$ \\
$\begin{array}{l}\text { 4. Embriotoxon posterior (examen } \\
\text { oftalmologic cu lampa cu fantă) }\end{array}$ & $\begin{array}{l}\text { 4. Facies caracteristic } \\
\text { 5. Facies caracteristic: triunghiular, } \\
\text { frunte proeminentă, ochi înfundați } \\
\text { în orbite, nas alungit cu vârf } \\
\text { bulbos, bărbie mică, ascuțită }\end{array}$ \\
\hline
\end{tabular}

Diferențierea sindromului Alagille de atrezia biliară are un impact major în ceea ce privește managementul ulterior; pacienții cu atrezia ductelor biliare extrahepatice efectuează o procedură chirurgicală paleativă - portoenterostomia Kasai - cu rezultate satisfăcătoare, dar, în cazul copiilor cu sindrom Alagille, operația Kasai este asociată cu o rată mai mare a mortalității, respectiv a necesității efectuării transplantului hepatic (9).

Investigația care confirmă diagnosticul de sindrom Alagille și exclude alte cauze de colestază (precum colestaza familială intrahepatică progresivă) este testarea cromozomială a genei JAG1 (20p12) $(1,10)$. Din rațiuni economice, testarea genetică nu a putut fi efectuată inițial în cazul pacientului nostru, însă ulterior a confirmat diagnosticul.

Biopsia hepatică nu este considerată obligatorie în stabilirea diagnosticului de certitudine (2). În cazul nostru, efectuarea biopsiei nu a adus niciun beneficiu deoarece rezultatul a fost neconcludent, probabil din cauza leziunilor nespecifice din ciroza hepatică deja instalată și a colestazei intrahepatice.

Ecografia abdominală este considerată de primă intenție în evaluarea imagistică a pacientului cu colestază, deoarece apreciază structura arborelui hepato-biliar și a parenchimului hepatic, decompensarea vasculară (gradul de hipertensiune portală) şi exclude eventualele anomalii renale (4). Prima evaluare ecografică a pacientului nostru nu a descris defecte ale căilor biliare intra/extrahepatice. Ultrasonografia este necesară atât pentru diagnostic, cât și pentru monitorizare ulterioară, având în vedere faptul că pacienții cu sindrom Alagille au risc crescut de a dezvolta ciroză și carcinom hepatocelular. Într-un studiu condus de Rapp şi colab., se atrage atenţia asupra puținelor date din literatură referitoare la apariția maselor hepatice în evoluția pacienților cu sindrom Alagille (11). Totuși, noduli regenerativi cu dimensiuni crescute se regăsesc la indivizii care au dezvoltat ciroză hepatică (aproximativ 30\% dintre pacienți). Acești noduli nu sunt de regulă maligni, ci apar, mai probabil, ca o adaptare funcțională la modificările vasculare $(5,12)$.

Colangio-IRM-ul reprezintă următorul pas în evaluarea noninvazivă. Totuși, această procedură nu este infailibilă: pot apărea rezultate fals pozitive secundare producției insuficiente de bilă într-un arbore biliar cu structură normală. Anomaliile vezicii biliare, precum diametrul redus sau defectele de formă, au o incidență crescută printre pacienții cu sindrom Alagille (9).

Managementul unui copil cu sindrom Alagille reprezintă de multe ori o provocare și necesită atenția unei echipe multidisciplinare (2). Copiii cu această patologie trebuie să beneficieze de o nutriție adecvată bazată pe diete bogate în carbohidrați și trigliceride cu lanț mediu (MCT). Pacientul nostru a primit formule speciale îmbogățite cu MCT și formule cu aminoacizi cu catenă ramificată. Corectarea deficitelor de vitamine liposolubile și oligoelemente (zinc) trebuie realizată cu doze orale optime astfel încât să le asigurăm acestor copii o dezvoltare corespunzătoare $(3,4)$. Pacientul nostru a primit suplimente per os cu vitamina $K$, vitamina $D$, vitamina $E$ și calciu.

Pacienții cu colestază cronică prezintă alterarea metabolismului colesterolului, a sintezei acizilor biliari, ceea ce impune medicație precum acidul ursodeoxicolic, care să reducă saturarea cu colesterol a acizilor biliari prin reducerea sintezei și secreției hepatice de colesterol, dar și prin reducerea reabsorbției intestinale a acestuia. Pruritul este de cele mai multe ori refractar la tratamentul medicamentos, astfel scăzând calitatea vieții. Există studii care descriu eficiența colestiraminei și a rifampicinei 
în diminuarea pruritului indus de acumularea acizilor biliari la nivel tegumentar $(2,4)$.

Imunizarea standard a copiilor cu sindrom Alagille este încurajată. Pacienții cu manifestări hepatice ar trebui sa primească vaccin antihepatitic A, iar dacă dezvoltă ascită, este obligatorie administrarea vaccinului antipneumococic multivalent pentru a preveni peritonita bacteriană spontană (4). Pacientul nostru a fost vaccinat conform schemei naționale, (BCG, antiVHB, antirubeolă, antirujeolă, antioreion, antidifteric, antitetanic, antipertussis, antipneumococic, antiHaemophilus influenzae B, antipoliomielitic).

Managementul chirurgical al copiilor cu sindrom Alagille include o procedură paleativă (drenajul biliar extern) și transplantul hepatic. Într-un studiu condus de Emerick şi colab., s-a raportat că, în cazul pacienților care au beneficiat de drenaj biliar extern, colestaza a diminuat, fără să existe o modificare în compoziția bilei (procedura deviază bila din circuitul entero-hepatic, însă nu influențează funcția hepatobiliară) (13).

Transplantul hepatic este luat în considerare în următoarele situații: disfuncție hepatică progresivă, hipertensiune portală severă, prurit refractar și osteodistrofie (4). Un bilanț pretransplant corespunzător trebuie să includă scorul PELD, care asociază mai mulți parametri clinici și de laborator - sex, vârstă, înălțime, valoarea albuminei serice, a bilirubinei și INR-ului. Acest scor se aplică copiilor cu vârsta sub 12 ani și se corelează cu prognosticul posttransplant (14). Pacientul nostru a prezentat o valoare promițătoare a scorului PELD, cu rată de supraviețuire la 1 an în așteptarea transplantului de $86,8 \%$ și în cazul efectuării transplantului de $93,6 \%$ la 1 an.

Rata medie de supraviețuire este de $80 \%$ la 5 ani posttransplant și de $60 \%$ la 20 de ani de la intervenție.

\section{BIBLIOGRAFIE}

1. Turnpenny PD, Ellard S. Alagille syndrome: pathogenesis, diagnosis and management. Eur J Hum Genet. 2012;20(3):251-7.

2. Hannoush Z., Puerta H, Bauer M, Goldberg R. New JAG1 Mutation Causing Alagille Syndrome Presenting With Severe Hypercholesterolemia: Case Report With Emphasis on Genetics and Lipid Abnormalities. The Journal of Clinical Endocrinology \& Metabolism. 2017; 102(2):350-353.

3. Genetic and Rare Diseases Information Centre. Alagille syndrome. Available from: https://rarediseases.info.nih.gov/diseases/804/ alagille-syndrome.

4. Scheimann A. Alagille Syndrome. Medscape Updated 2016. Available from: https://reference.medscape.com/article/926678-overview.

5. Ennaifer R, Farhat SB, Cheikh M, Romdhane H, Marzouk I, Belhadj $\mathrm{N}$. Focal liver hyperplasia in a patient with Alagille syndrome: Diagnostic difficulties. A case report. International Journal of Surgery Case Reports. 2016;25:55-61.

6. Nischal K, Hingorani M, Bentley C, Vivian A, Alan C. Bird, Alistair J. Baker, Alex P. Mowat, Georgina Mieli-Vergani, Wagih A. Aclimandos.
Totuși, datele arată că rata de eșec a transplantului hepatic la pacienții cu sindrom Alagille este mai mare comparativ cu cei care prezintă atrezie biliară extrahepatică (4).

O problemă importantă în privința transplantului o constituie grefele provenite de la rudele de gradul I. Chi-Ning Lee şi colab. au raportat un caz în care transplantarea s-a sistat în sala de operații deoarece biopsia grefei a evidențiat paucitate de căi biliare (15). Donatorul în cazul pacientului nostru este tatăl, deoarece gena dominantă a fost transmisă, cel mai probabil, pe cale maternă (având în vedere dismorfismul facial și malformația cardiacă a mamei), dar problema cea mai importantă a fost prezența steatozei hepatice la tată.

Dacă există anomalii cardiace structurale severe precum tetralogia Fallot, chirurgia cardiacă pentru corectarea defectului este obligatorie, cu o rată de supraviețuire la 20 de ani de 40\% (4). În cazul nostru, pacientul a asociat stenoză pulmonară largă, fără indicație chirurgicală.

\section{CONCLUZII}

Sindromul Alagille pune în anumite situații probleme diagnostice, în special din cauza fenotipului variabil și a posibilităților limitate de efectuare a testelor genetice de confirmare. Totuși, în prezența criteriilor clasice, diagnosticul acestei patologii genetice nu ar trebui ratat.

Abordarea terapeutică la pacienții cu sindrom Alagille necesită atenția unei echipe multidisciplinare, care să monitorizeze statusul nutrițional, activitatea cardiovasculară și boala hepatică cronică, să stabilească momentul transplantului hepatic și să îl realizeze.

Conflict of interest: none declared Financial support: none declared

Ocular Ultrasound in Alagille Syndrome: A New Sign. Ophthalmology. 1997;104(1):79-85.

7. Kamath BM, Spinner NB, Emerick KM et al. Vascular anomalies in Alagille syndrome: a significant cause of morbidity and mortality. Circulation. 2004;109: 1354-1358.

8. Hartley J. The jaundiced baby. Deidre Kelly (eds): Diseases of the Liver and Biliary System in Children, 4th Edition, Blackwell Publishing Ltd. 2008: 99-126.

9. Han S, Jeon TY, Hwang SM et al. Imaging findings of Alagille syndrome in young infants: differentiation from biliary atresia. $\mathrm{Br} J$ Radiol. 2017;90:1077.

10. Pati GK, Singh A., Nath P et al. A 10-year-old child presenting with syndromic paucity of bile ducts (Alagille syndrome): a case report. J Med Case Reports. 2016;10:342.

11. Rapp JB, Bellah RD, Maya C, Pawel BR, Anupindi SA. Giant hepatic regenerative nodules in Alagille syndrome. Pediatr Radiol. 2017;47(2):197-204. 
12. Andrews AR, Putra J. Central Hepatic Regenerative Nodules in Alagille Syndrome: A Clinicopathological Review. Fetal Pediatr Pathol. 2019;14:1-11.

13. Emerick K, Melin-Aldana H, Strautnieks S, Thompson R, Bull L, Knisely AS et al. Bile composition in Alagille Syndrome and PFIC patients having Partial External Biliary Diversion. BMC Gastroenterol. 2008;8:47.
14. Boudi B. Pediatric Liver Transplantation. Medscape Updated Mar 17, 2019. Available from: https://emedicine.medscape.com/ article/1012910-overview.

15. Lee CN, Tiao MM, Chen HJ, Concejero A, Chen CL, Huang YH. Characteristics and Outcome of Liver Transplantation in Children with Alagille Syndrome: A Single-center Experience. Pediatrics and Neonatology. 2014;55:135e138. 